\title{
ANTHROPOGENIC TRANSFORMATION OF THE VEGETATION IN THE IMMEDIATE VICINITY OF THE SETTLEMENT COMPLEX AT POGANOWO (MRĄGOWO LAKELAND, NE POLAND)
}

\author{
Marta Szal $^{1}$, Mirosława Kupryjanowicz ${ }^{1}$, Mariusz Wyczółkowski ${ }^{2}$ \\ ${ }^{1}$ Institute of Biology, University of Biatystok, Świerkowa 20b, 15-950 Biatystok, Poland; \\ e-mail:martaszal@op.pl,m.kupryjanowicz@uwb.edu.pl \\ ${ }^{2}$ Wojciech Kętrzyński Museum, Plac Zamkowy 1, 11-400 Kętrzyn, Poland; e-mail: mw@muzeum.ketrzyn.pl
}

\begin{abstract}
The results of pollen, non-pollen palynomorph and microcharcoal particle analyses of deposits from a small pond in northeastern Poland are presented. The study focused on human-induced vegetation changes that occurred in a close vicinity of the settlement complex at Poganowo during the Middle Ages ( $c a 10^{\text {th }}-16^{\text {th }}$ centuries). We distinguished three phases of human impact. First and third phases correspond to intensified settlement activity. The second phase was a period when human activity decreased and woodland regeneration took place. The high incidence of the parasitic fungus Kretzschmaria deusta in a local forest stand during the third phase was simultaneous with numerous spores of coprophilous fungi (Sordaria-type and Cercophora-type). We consider that Kretzschmaria deusta inhabited the roots and bases of tree trunks damaged by digging and grazing animals.
\end{abstract}

Key words: human impact, pollen analysis, fungal spores, Masuria, Middle Ages.

Mansuscipt received 1 December 2014, accepted 1 June 2015

\section{INTRODUCTION}

A use of indicator characteristics of some plant taxa, as well as of other organisms, is a fundamental method in palaeoecology, enabling reconstruction of past environments (e.g. Birks, 2003; Latałowa et al., 2013). Among the microfossils that are observed in pollen slides, fungi, algae and other non-pollen palynomorphs (NPP) have become particularly important, because of their potential to improve reconstruction of past ecosystems (van Geel, 2001; van der Linden et al., 2012). Van Geel and Aptroot (2006) underlined that fungal remains are of high potential in this context. In particular, these authors emphasized the importance of fungal taxa with well-characterized biological and ecological requirements, e.g. Sporormiella sp. and Sordaria sp., which are indicators for dung, or Kretzschmaria deusta, a parasite on decaying wood, indicating presence of their host trees. However, a palaeoecological potential of fungal remains has not yet been fully explored. We present results of palynological analysis in the framework of interdisciplinary research project conducted in the settlement complex at Poganowo (Szal et al., 2013; Wyczółkowski et al., 2013). This settlement complex is located entirely in a forest, and nearby there are numerous small peat bogs and ponds suitable for local-scale vegetation reconstructions (compare Sugita et al., 2007). Our main objective was to study trans- formation of vegetation caused by human activity. Moreover, by the application of NPP and microcharcoal particle analysis we tried to characterize farming models, assuming the possibility of attributing the presence of spores of coprophilous fungi (e.g. Sordaria-type, Sporormiella-type) to land-use practices, particularly husbandry.

\section{ARCHAEOLOGICAL AND HISTORICAL BACKGROUND}

The settlement complex at Poganowo is located in the northeastern part of the Mragowo Lakeland. The earliest traces of human activity in the region have been dated to the Neolithic period. Nevertheless, generalization of permanent settlements occurred with the beginning of the West Balt Barrow culture in the early Iron Age ( $c a 7^{\text {th }}$ century BC). The first settlement phase in the Poganowo hillfort is linked to this culture (Wyczółkowski et al., 2013), and the charcoal and ash layer (perhaps from burnt timber constructions of ramparts or palisades) of this phase are dated to the $6^{\text {th }}-4^{\text {th }}$ century BC. Other sites, located a short distance from Poganowo, include the fortified settlement at Nakomiady, the settlement in Wólka, and the barrow cemeteries in Godzikowo and Nakomiady, also dated to the early Iron Age (Hoffmann, 1999; Wyczółkowski, 2011). 


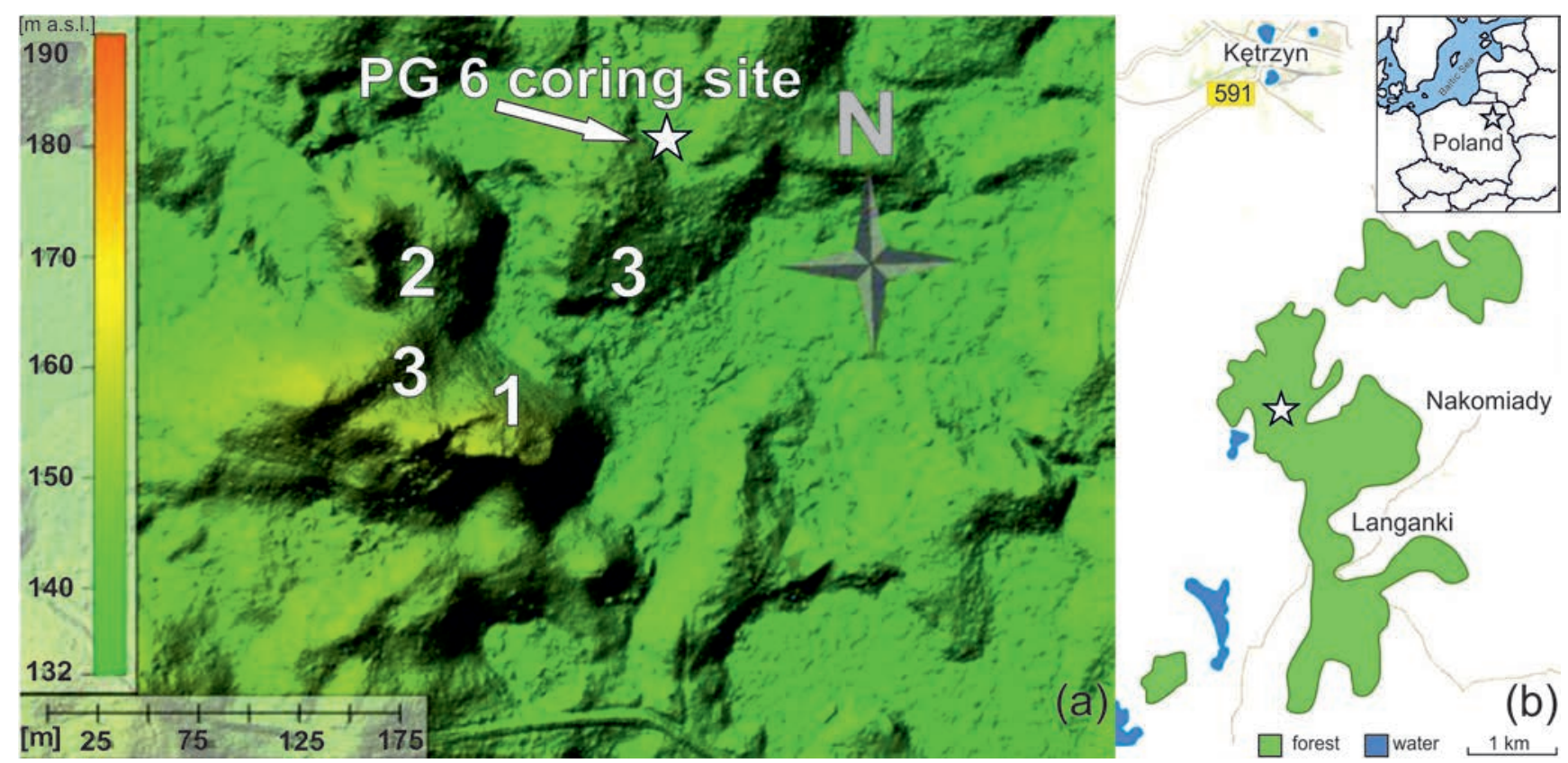

Fig. 1. Location of the study area produced by using the digital terrain model from LIDAR data (a) and Google Maps (b) with PG6 coring site $\left(54^{\circ} 00^{\prime} 11.2^{\prime \prime} \mathrm{N} 21^{\circ} 23^{\prime} 04.6^{\prime \prime} \mathrm{E}\right) ; 1$-Poganowo hillfort, 2 - sacrificial place, 3 - settlements.

An increase in a number of sites related to the population of the Bogaczewo culture during the Roman Period $\left(1^{\text {st }}-4^{\text {th }}\right.$ century AD) has been observed (Szymański, 2005). At that time, two settlements existed in the vicinity of the Poganowo hillfort. There is a cemetery in Turwagi (Voß, 1886), and a settlement and sacrificial bog site at Wólka (Raddatz, 19921993).

A second settlement phase in the Poganowo hillfort has been dated to the late $10^{\text {th }}-12^{\text {th }}$ centuries AD. In northeastern Poland this period is called the Early Middle Ages or the Viking Age (e.g. Nowakiewicz, 2006, 2010; Nowakiewicz and Wróblewski, 2010). At that time, a sacrificial place existed, and an extensive settlement has been excavated (Wyczólkowski et al., 2013). Radiocarbon dating (1338 \pm 58 AD) from the hearth of the sacrificial place may indicate a use of this place as late as in the $13^{\text {th }}$ and $14^{\text {th }}$ centuries.

In the second half of the $14^{\text {th }}$ century the forest where the Poganowo hillfort is located was given to the city of Kętrzyn (Rastenburg). From the first half of the $15^{\text {th }}$ century the villages began to develop (Beckherrn, 1880). Finally, in 1571 $\mathrm{AD}$, the villages Pręgowo, Sławkowo and Poganowo, located in the northern and western part of the forest, included 93 hufen ( 1 hufe is $c a 16.8$ ha) that were managed by 43 farmers (Visitation, 1571). The number of farms existing on the edge of Poganowo did not change significantly until the end of the $18^{\text {th }}$ century (Goldbeck, 1785).

\section{MATERIAL AND METHODS}

\section{Coring and lithology}

The sediment core (PG6 profile) was collected in winter of 2012 from a small pond located $c a 150 \mathrm{~m}$ to the northeast of the settlement complex at Poganowo (Fig. 1). Coring was performed by using an Instorf peat sampler. The core contained sandy peat $(0.9-0.78 \mathrm{~m}$ depth) and fen shrub peat (0.78-0.2 m depth; D. Drzymulska, personal comm.). For technical reasons the highly hydrated topmost part of the deposit could not be retrieved.

\section{Pollen analysis}

Samples of $1 \mathrm{~cm}^{3}$ were prepared using the standard procedure of Erdtman's acetolysis (Berglund and Ralska-Jasiewiczowa, 1986). Depending on the content of mineral matter the samples were treated with a heavy liquid $\left(\mathrm{CdI}_{2}+\mathrm{KI}\right)$. The palynological analysis was performed on 35 samples from the PG6 profile. Pollen analysis was carried out with an Olympus BX43 light microscope with magnification of $600 \times$; a larger magnification was used to identify problematic and small palynomorphs. The identification of cereal-type pollen was based on phase contrast studies under $1000 \times$ magnification. For taxonomical identification pollen keys (e.g. Beug, 2004) and a reference collection of modern pollen slides were used. On average 900 terrestrial pollen grains were counted and identified in each sample.

\section{Analysis of non-pollen palynomorphs and microcharcoal}

Non-pollen palynomorphs (NPPs) were counted along with the pollen analysis, and identified according to van Geel (1978, 2001), Bell (1983), Jankovská and Komárek (2000), van Geel et al. (2003) and van Geel and Aptroot (2006).

Microcharcoal particles were counted in the pollen slides and grouped into four size classes: $10-30 \mu \mathrm{m}, 30-70 \mu \mathrm{m}$, $70-100 \mu \mathrm{m}$ and $>100 \mu \mathrm{m}$. According to Tinner and $\mathrm{Hu}$ (2003) the larger particles better reflect the incidence of local 
fires, whereas the smaller particles are more indicative of regional fires. Particles $<10 \mu \mathrm{m}$ were ignored, as they cannot be safely identi ed (Blackford, 2000). One tablet containing 20,848 marker spores of Lycopodium was added to each sample to enable a quantitative analysis of microfossil concentrations (Stockmarr, 1971). Charcoal particles were recorded with a light microscope at $400 \times$ magnification. Charcoal selection was restricted to fragments that were black, completely opaque and angular (Whitlock and Larsen 2001).

Calculations and the presentation of palynological and microcharcoal data were performed with POLPAL for Windows (Nalepka and Walanus, 2003). The AP+NAP sum was used for percentage calculations, both in the pollen and the NPP diagrams. The pollen diagram was stratigraphically ordered and zoned with Constrained Cluster Analysis (CONISS), and divided into local pollen assemblage zones (LPAZ), which were named according to the specific composition of pollen spectra. The human impact groups follow Behre (1981), Berglund and Ralska-Jasiewiczowa (1986), and Gaillard and Berglund (1988).

Principal component analysis (PCA) served for the detection of interspecies relationships. The analysis was based on data from all pollen samples; sporadically occurring arboreal taxa and non-arboreal taxa were excluded. PCA was carried out using XLSTAT 2014 trial version software.

\section{Chronology}

The age of one sediment sample from a depth of $0.48 \mathrm{~m}$ was determined by radiocarbon dating $\left({ }^{14} \mathrm{C} / \mathrm{AMS}\right)$ in the Gliwice Radiocarbon Laboratory, Institute of Physics, Silesian University of Technology (Table 1).

\section{RESULTS}

\section{Local pollen assemblage zones}

The pollen diagram was divided into three LPAZ (from LPAZ PG6-1 to LPAZ PG-3), which correspond to the subsequent phases of vegetation development in the immediate vicinity of the sampling site (Fig. 2). The pollen zones are described (Table 2).

\section{Principal Component Analysis (PCA)}

It describes statistically possible relationships between arboreal pollen and the fungal spores record (Fig. 3). The results indicated that there may be a distinct positive correlation between the pollen record of forest species, e.g. Quercus, Alnus, Picea abies, Carpinus betulus, and the spores of the parasitic fungus Kretzschmaria deusta and the coprophilous fungi Sordaria-type and Cercophora-type.

\section{INTERPRETATION AND DISCUSSION}

\section{Reconstruction of vegetation dynamics and human impact}

The changes in the composition of the pollen assemblages recorded in the PG6 profile enabled to distinguish three phases of vegetation dynamics connected with human activity (Fig. 2).
Table 1

AMS radiocarbon dates from the PG6 core used for chronology

\begin{tabular}{|c|c|c|c|c|}
\hline $\begin{array}{c}\text { Depth } \\
(\mathrm{cm})\end{array}$ & Lab. No. & $\begin{array}{c}\text { Age }{ }^{14} \mathrm{C} \\
\text { (BP) }\end{array}$ & $\begin{array}{c}\text { Calibrated age range } \\
68 \% \\
\text { (calendar age, AD) }\end{array}$ & $\begin{array}{c}\text { Calibrated age range } \\
\text { 95\% } \\
\text { (calendar age, AD) }\end{array}$ \\
\hline 48 & GdA-3545 & $695 \pm 25$ & $1274(68.2 \%) 1296$ & $\begin{array}{c}1266(78.4 \%) \\
1362(17.0 \%)\end{array} 1385$ \\
\hline
\end{tabular}

\section{First phase (LPAZ PG6-1)}

Vegetation changes in the study area at the beginning of this phase represent a period of strong human impact. Pollen spectra illustrate occurrence of a pine-birch forest, where the undergrowth was dominated by hazel. The existence of open surfaces and/or good light conditions on the forest floor is indicated by the presence of Juniperus communis pollen. Moreover, Juniperus communis indicates that dry and moderately moist soils occurred near the study site, what can be deduced from edaphic requirements of this species (Zarzycki, 2002). The abundant occurrence of microcharcoal particles, in all size classes, may re ect human impact on the environment. The presence of Melampyrum and Pteridium aquilinum, which are considered indicators of soil enrichment by ash (Latałowa, 2007), additionally confirms the occurrence of fires in the area. Most probably, it was intentional use of fire, pointing to activity within the settlement and to woodland clearing. The palynological data reveal the existence of large open areas near the sample site, as indicated by nearly $20 \%$ of NAP. A considerable area was covered by meadows and pastures, represented mainly by Poaceae, Cyperaceae, Filipendula and Centaurea nigra-type, and ruderal communities with Artemisia and Chenopodiaceae. Only small plots were used as fields.

In the investigated water body aquatic macrophytes like Potamogeton, Nymphaea alba, Nymphaea candida and Nuphar occurred. Along the lakeshore reed swamp communities with Typha latifolia and Typha angistifolia occurred. Numerous green algae, including Tetraedron, Pediastrum and Botryococcus, developed in the water body. These algae, as well as cyanobacteria of the Gloeotrichia-type, play an important role in inferring past lake conditions, and almost all are known to be dominant in more eutrophic systems (e.g. van Geel and Grenfell, 1996; Jankovská and Komárek, 2000). Moreover, Gloeotrichia is one of the most important organisms today causing so called 'water blooms', linked to the enrichment of the aquatic environment with phosphorus and nitrogen (Burchardt and Pawlik-Skowrońska, 2005). We may assume that the relatively high trophic status of the investigated water body was probably due to a large supply of nutrients in response to the intensive settlement activity in this area.

Linking the first phase of anthropogenic vegetation changes with a de nite cultural event is not possible due to the availability of only one radiocarbon date from a depth of $0.48 \mathrm{~m}$ in this section. However, it could be related tentatively to the second phase of occupation of the hillfort at Poganowo, dated to the early Middle Ages $\left(10^{\text {th }}-12^{\text {th }}\right.$ centuries AD). Archaeobotanical analysis of the early medieval layers and hearths 


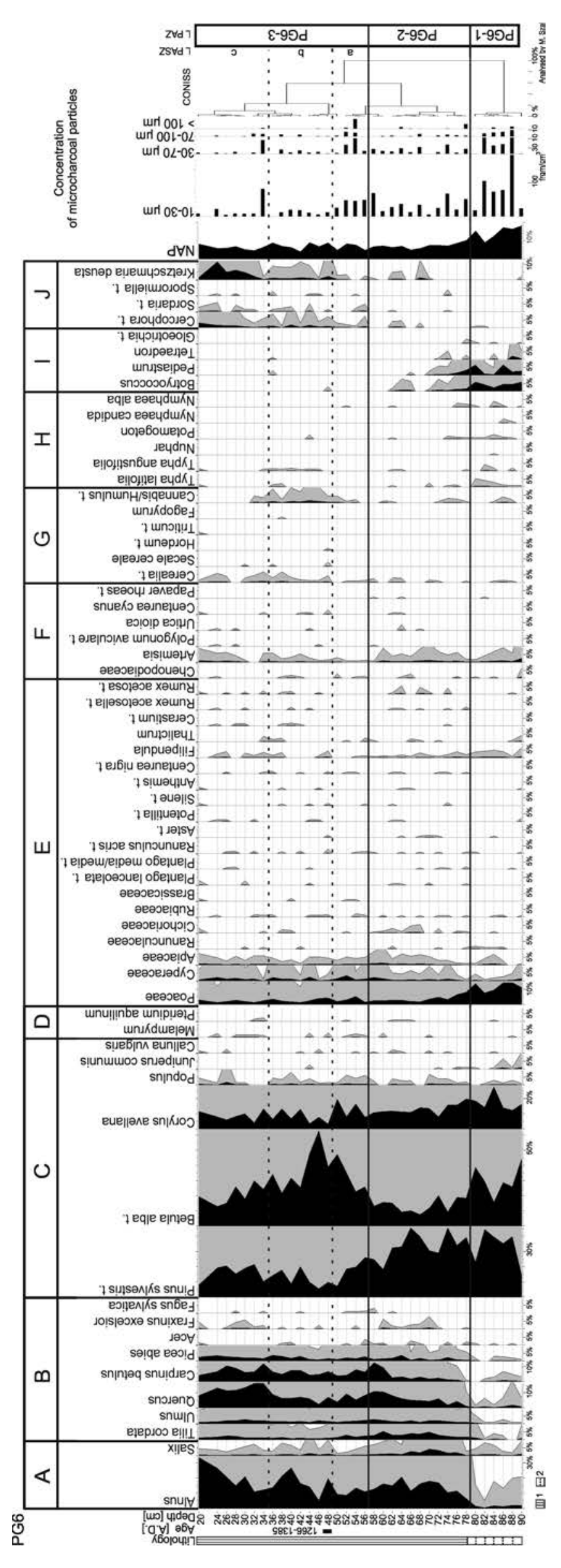

$\infty$ 胥 क्ष . 苍 3 फ 를 政 安的 within the settlement complex at Poganowo confirmed a cultivation of cereals in this time. Remains of barley (Hordeum vulgare), millet (Panicum miliaceum), wheat (Triticum), rye (Secale cereale) and oats (Avena) were found (K. Pińska, personal comm.). According to Wyczółkowski and Makowiecki (2009), it can be claimed that the inhabitants of the early mediaeval settlement at Poganowo raised cattle and horses.

\section{Second phase (LPAZ PG6-2)}

The period of intensive exploitation of the environment during the first phase was followed by a phase of decreased human activity (decrease in NAP frequency and concentration of microcharcoal particles) leading to the forest regeneration. Then, considerable changes in forest composition occurred. An increase of Quercus pollen is synchronous with an increase in pollen of the other main arboreal taxa: Tilia, Ulmus, Carpinus, Picea, Fraxinus, and expansion of Salix shrubs. The vicinity of the studied site became almost completely forested. Dry morainic hills were overgrown by mixed pine forests. Patches of fertile, fresh soils were covered by oak-hornbeam forest, with an admixture of spruce. Considerable areas in the lakeshore zone and in other wet places were covered by alder woods and carrs. At this phase, forest regeneration relates to a very low level of human exploitation of the landscape and possibly reflects the time when the Poganowo settlement complex was abandoned. There is an assumption that this could have happened in the early $13^{\text {th }}$ century (M. Wyczółkowski, personal comm.). According to historical sources (Saage and Woelky, 1860), in the surroundings of the Poganowo hillfort there was a large forested area called Tauro ("Walt Tauro"), which was mentioned in documents dated to 1231-1340 AD. Nevertheless, pollen spectra from the PG6 section indicate that some pastoral agriculture seems to have been practiced at this time, as well as arable farming. According to Vuorela (1973), Cerealiatype pollen grains are not well dispersed in airstreams, and therefore their poor representation cannot be considered as a guide to the importance of crop farming in the area. Admittedly, some weeds of arable fields were present in the pollen record, but in low frequencies only. The appearance of Centaurea cyanus was probably connected with the cultivation of winter crops. Other weeds documented in the PG6 pollen profile include Chenopodiaceae, Papaver and Polygonum aviculare. Cannabis/Humulus-type pollen most probably indicates that Humulus lupulus grew in this area as a native plant on damp soils.

The area of meadows significantly decreased, but a low-level presence of Plantago lanceolata, Rumex acetosella-type, Rumex acetosa-type and Cichoriaceae pollen grains indicates that some open 
Table 2

Local pollen assemblage zone description from PG6 core diagram

\begin{tabular}{|c|c|}
\hline Name of L PAZ and depth & Description \\
\hline $\begin{array}{l}\text { PG6-1 } \\
\text { Pinus-Betula-Poaceae } \\
90-80 \mathrm{~cm}\end{array}$ & $\begin{array}{l}\text { Dominance of Pinus sylvestris-type (14-43\%) and Betula alba-type (15-45\%). High values of Corylus avellana (to } 19 \% \text { ) } \\
\text { with short-lasting peak (27\%) in the middle part of zone. Several percentage frequency of Alnus (to } 2 \% \text { ) and Quercus (to } \\
1.5 \%) \text {. Sporadic presence of other tree taxa. Relatively frequent Juniperus communis. Considerable participation of NAP } \\
(9-18 \%) \text {. The herbaceous spectra dominated by Poaceae (to } 15 \% \text { ). Regularly present Filipendula. Among the anthropo- } \\
\text { genic indicators, systematic presence of Artemisia, Chenopodiaceae and Cerealia-type. Frequent pollen grains of } \\
\text { limnophytes, such as Potamogeton and Typha latifolia. Regular occurrence of green algae (Botryococcus, Pediastrum, } \\
\text { Tetraedron) and single remains of cyanobacteria (sheaths of Gloeotrichia). Very high concentration of microscopic char- } \\
\text { coal particles. }\end{array}$ \\
\hline $\begin{array}{l}\text { PG6-2 } \\
\text { Alnus-Pinus-Quercus-Tilia } \\
78-58 \mathrm{~cm}\end{array}$ & $\begin{array}{l}\text { Increase of Alnus above 20\%. Significant decrease of Betula alba-type. Dominance of Pinus sylvestris-type (20-47\%). } \\
\text { High values of Corylus avellana (to 14\%). Increasing curves of Tilia cordata (to 7\%), Ulmus (to 3\%), Quercus (to 12\%), } \\
\text { Carpinus betulus (to 12\%), Picea abies (to 4\%) and Salix (to 4\%). Less numerous NAP (6-9\%). Gradual decrease of } \\
\text { Poaceae (to 3\%). Frequent Filipendula, Cyperaceae, Apiaceae and Cichoriaceae. Regular occurrence of Artemisia. In sev- } \\
\text { eral spectra, presence of Cerealia-type, Centaurea cyanus-type, Plantago lanceolata, Rumex acetosella-type, Rumex } \\
\text { acetosa-type and Chenopodiaceae. Decreasing values of green algae. Single occurrences of coprophilous fungi } \\
\text { (Sporormiella-type, Sordaria-type and Cercophora-type). Sporadic Kretzschmaria deusta. Relatively low concentration of } \\
\text { microscopic charcoal particles. }\end{array}$ \\
\hline $\begin{array}{l}\text { PG6-3 } \\
\text { Betula-Quercus-Carpinus- } \\
\text { Alnus } \\
56-20 \mathrm{~cm}\end{array}$ & $\begin{array}{l}\text { ominance of Betula alba-type, Pinus sylvestris-type and Alnus. Constant presence of Tilia cordata, Quercus, Carpinus } \\
\text { etulus and Ulmus. The PG6-3 LPAZ was divided into three subzones. }\end{array}$ \\
\hline $\begin{array}{l}\text { PG6-3a } \\
\text { Betula-Corylus } \\
56-50 \mathrm{~cm}\end{array}$ & $\begin{array}{l}\text { Fast increase of Betula alba-type (to } 48 \% \text { ). High values of Corylus avellana (to } 20 \% \text { ). Frequent Populus. Gradual de- } \\
\text { crease of Pinus sylvestris-type (to } 8 \% \text { ). Relatively high values of Alnus (10-13\%), Quercus (4-10\%) and Carpinus betulus } \\
(5-11 \% \text { ). More frequent Poaceae (to } 7 \% \text { ) and Cyperaceae (to } 4 \% \text { ). Decreasing values of Apiaceae, Filipendula and } \\
\text { Cerealia-type. Lower frequency of Artemisia. Relatively frequent Cercophora-type. Sporadic occurrence of Sporo- } \\
\text { rmiella-type, Sordaria-type and Kretzschmaria deusta. Relatively high concentration of microscopic charcoal particles. }\end{array}$ \\
\hline $\begin{array}{l}\text { PG6-3b } \\
\text { Betula-Alnus } \\
48-36 \mathrm{~cm}\end{array}$ & $\begin{array}{l}\text { Strong increase of Betula alba-type to } 63 \% \text {, then decrease to } 24 \% \text {. Increasing percentage values of Pinus sylvestris-type } \\
\text { (to } 21 \% \text { ). Lower values of Corylus avellana (4-12\%) and Populus (to } 1 \% \text { ). Fluctuating increase of Alnus (to } 28 \% \text { ). Grad- } \\
\text { ual decrease of Poaceae. More frequent Artemisia and Cannabis/Humulus-type. Regular occurrence of Cerealia-type and } \\
\text { single occurrences of Secale cereale and Hordeum-type. Sporadic Centaurea cyanus-type, Plantago lanceolata, Rumex } \\
\text { acetosella-type, Rumex acetosa-type. More frequent Cercophora-type and Kretzschmaria deusta. Sporadic } \\
\text { Sporormiella-type and Sordaria-type. Much lower concentration of microscopic charcoal particles. The age of the sedi- } \\
\text { ment at } 0.48 \text { m depth was estimated at } 1266-1385 \text { AD (Table 1). }\end{array}$ \\
\hline $\begin{array}{l}\text { PG6-3 } \\
\text { Quercus-Carpinus- } \\
\text { Kretzschmaria } \\
34-20 \mathrm{~cm}\end{array}$ & $\begin{array}{l}\text { High values of Quercus (to } 16 \% \text { ) and Pinus sylvestris-type (to } 20 \% \text { ). Increasing tendency of Alnus (to } 34 \% \text { ). Gradual de- } \\
\text { crease of Betula alba-type (to } 15 \% \text { ). Carpinus betulus oscillating around } 7-11 \% \text {. Constant presence of Corylus avellana } \\
\text { (to } 12 \% \text { ). Higher values of Artemisia. Regularly occurring Poaceae, Cyperaceae and Apiaceae. More frequent Plantago } \\
\text { lanceolata, Rumex acetosa-type and Ranunculaceae. Sporadic Rumex acetosella-type. Temporary decreasing tendency of } \\
\text { Cerealia-type. Strong increase of Kretzschmaria deusta to } 12 \% \text {. Increasing tendency of Cercophora-type. Sporadic occur- } \\
\text { rence of Sporormiella-type and Sordaria-type. Low concentration of microscopic charcoal particles. }\end{array}$ \\
\hline
\end{tabular}

herbaceous plant communities occurred as fodder for domesticated herbivores.

LPAZ PG6-2 represents a period of generally low anthropogenic activity in the catchment area and, based on decreased percentages of Botryococcus, Pediastrum, Tetraedron and Gloeotrichia, eutrophication diminished. However, the decrease of algae and some aquatic plants coincides also with sedimentological changes. It should be underlined that local terrestrialization, a transition from wetland to drier peat, could be an alternative explanation for the decline in algae and cyanobacteria.

\section{Third phase (LPAZ PG6-3)}

The pollen record from this core interval enabled to determine three sub-phases that indicate response of local vegetation to a variability of human activity dated to $13^{\text {th }}-16^{\text {th }}$ centuries AD.

Fig. 3. PCA plot illustrating the interspecies relationships in the pollen spectra from the PG6 core.

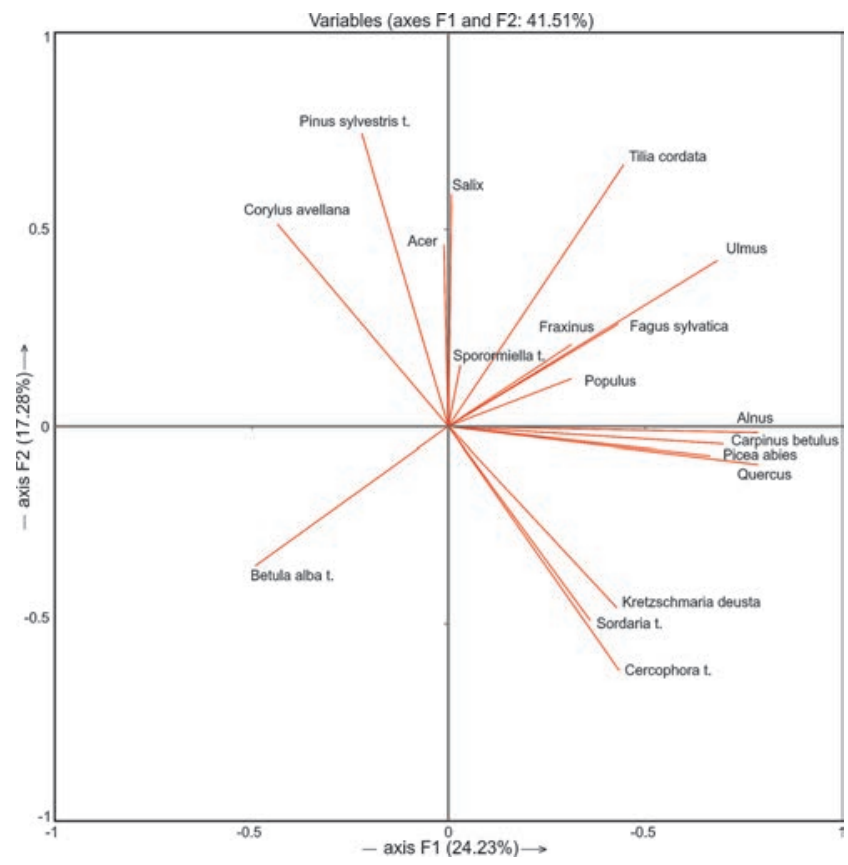


In the oldest part (LPAZ PG6-3a) the most characteristic phenomenon was woodland clearance and the expansion of birch. Microscopic charcoal concentrations steeply increased, indicating the presence of fire events in the vicinity. Moreover, the presence of spores of Pteridium aquilinum, which easily colonizes disturbed ground, including burnt areas (Hartig and Beck, 2003), may also point to fires. The fires could have served as a silvicultural tool for deforestation, or just to create openings in a tree canopy. Local development of birch woodland and shrubs is perhaps associated with Betula, featuring as a prominent pioneer species after fires (Connor et al., 2012; Lindbladh et al., 2003). Moreover, at the beginning of this phase Alnus also increases, which plausibly illustrates its fire-related behaviour. Alder was classified by Tinner et al. (2000) to the group of taxa whose abundance largely depends on fire. The rapid increase in the pollen values of the light-demanding Corylus, accompanied by the more frequent Populus, is evidence for forest opening. Corylus as an understory species produces little pollen under a heavy tree canopy, and large quantities of hazel pollen may result from bushes growing at the woodland margin and in clearings (Rackham, 1988). In our investigation high frequencies of Corylus pollen, up to $22 \%$, suggest that hazel had a dominant position in the vegetation, indicating that pollen dispersal was hardly hindered by trees. However, there were more changes in the woodland composition that occurred as consequence of forest fires. A reduction of deciduous tree pollen was observed, particularly of Tilia, Quercus and Carpinus, which grew on more fertile soils and this may indicate that more land was needed for arable fields. The importance of Pinus and Ulmus gradually decreased. However, elm was still present on fresh, fertile and moderately mesotrophic soils. Locally, wet alder woods may have grown in depressions, around the lake and on mires. There were slightly larger areas covered by meadow vegetation, in the PG6 pollen profile mainly represented by Poaceae, Cyperaceae, Apiaceae, Brassicaceae, Rubiaceae, Silene-type, Thalictrum and Centaurea nigra-type. Probably, there were also relatively small-cultivated areas and grazed grasslands situated close to the lake. It is also possible that deforestation took place because of the need to acquire new residential areas. However, it is difficult to determine the causes of forest destruction, especially because there is no archaeological evidence for construction materials and no anthracological data from the Poganowo settlement complex.

Pollen spectra from LPAZ PG6-3b indicate the predominance of forest communities, with Betula playing the most significant role, as suggested by its pollen values of up to $60 \%$. Huntley and Birks (1983) assumed that Betula pollen values larger than 50\% indicate Betula-dominated woodlands in the landscape. Szal et al. (2014) discussed the problem of the long-lasting dominance of Betula in the Iron Age and in the Migration Period, particularly in the area of Lake Salęt, situated close to the site investigated here. It was concluded that Betula expansion was connected with agricultural practices within the settlement region. In the case of the Poganowo area, the high Betula participation may indicate that this land was cleared repeatedly in order to prevent the re-growth of woodland and to enable effective crop farming. Cereal cultivation indicators recorded in the PG6 profile show that
Secale, Hordeum and Fagopyrum were among the cultivated plants. However, the spectrum of herbaceous taxa mainly points to the existence of meadows (pollen of Poaceae, Centaurea nigra-type, Filipendula). In the surroundings of the investigated site, there occurred also ruderal plants, such as Artemisia, Urtica and Chenopodiaceae, which, according to Behre (1981), are associated with nitrogen-rich habitats. They may also have grown along the nitrogen-rich banks of the lake. In tree-less parts of the landscape grazed grasslands were present, as indicated by Plantago lanceolata, Plantago major/media, Potentilla-type, Cerastium-type, Rubiaceae, and Cichorioideae, which are considered to indicate pastoral activities (Mazier et al., 2006; Hjelle, 1999). Moreover, Mazier et al. (2006) concluded that Plantago lanceolata, Plantago major/media and Chenopodiaceae could be also treated as indicators of woodland grazing. This may indicate that domesticated herbivores grazed close to the sampling site. In addition, pollen grains of Polygonum aviculare and Rumex acetosella-type were recorded. These weeds thrive on trampled, disturbed ground, and were classified by Pokorná et al. (2014) as reliable indicators of trampled vegetation.

In the youngest sub-phase (LPAZ PG6-3c) a significant spread of Quercus was observed. This process was accompanied by an increase of Carpinus betulus and Pinus sylvestris contemporaneous with a decrease in Betula and Picea abies. The pollen record shows that the surroundings of the study site were overgrown by mixed pine-oak forests and by rich, deciduous lime-oak-hornbeam forests. Areas occupied by hygrophilous Alnus increased, suggesting the development of swampy alder forest with Fraxinus excelsior. We suppose that the observed changes in species composition, mainly the dominance of Quercus, developed under the substantial in uence of human activity, and to some extent were associated with moderate livestock grazing in woodland. The occurrence of trampled and grazed areas near the study site is illustrated by presence of Polygonum aviculare, Plantago lanceolata-type, Potentilla-type, Cerastium-type, Rumex acetosatype and Rumex acetosella-type. It is worth mentioning that in mediaeval documents related to the study area there are several place names indicating open oak woods with woodpasture practices. For example, the name of the village Nakomiady ('Eichmedien') (eiche - an oak tree; median - the Prussian forest), may indicate the existence of oak wood (Gerullis 1922). Additionally, Beckherrn (1885) mentioned the area named 'Damerau', situated close to the study site since 1393. Gross (1935) claimed that in medieval times this name was commonly used to describe deciduous forest, mainly with oak trees, where domesticated pigs were fattened on acorns, a practice known as pannage. Moreover, according to Beckherrn (1889), and Wyczółkowski and Makowiecki (2009), it can be claimed that the inhabitants of the medieval Poganowo settlement complex raised cattle and horses.

It is not clear to what degree herbivores can influence long-term patterns of plant abundance, dynamics and distribution (Maron and Crone, 2006). Despite this, some scientists (e.g. Flannery, 2003) claim that there is a clear correlation between oak forest and the introduction of grazing herds into the primeval forests in medieval times. Faliński (1986) described the dominance of Quercus in Białowieża Forest as a result of grazing. However, different animal spe- 
cies are likely to have different effects, with larger animals likely to cause more physical damage by breaking branches, eating saplings and seedlings, or trampling the herbaceous vegetation. Cattle and other large herbivores may have created clearings, or at least more open woodland, allowing light to reach the ground and to support a growth of herbaceous plants on the woodland floor. In the PG6 section there are clear signs of small landscape openness and reductions in a tree canopy, leading to understory development with lightdemanding Pteridium aquilinum and Calluna vulgaris. Moreover, in some areas where livestock grazing was suspended increased flowering/re-sprouting of Corylus avellana and Populus could occur.

Faliński (1986) noticed that in Białowieża Forest changes in species composition occurred that were associated with a reduction in grazed areas. The species of open habitats gradually declined and mesophytic Carpinus replaced Quercus. This led to the loss of species assemblages typical for subcontinental oak woods (Kwiatkowska et al., 1997). The maintenance of oak woodlands in the past was also discussed by Szabó (2013). According to this author, traditional forest management was not a driving factor in a distribution of various forest types, while oak wood might be an exception. Because of the economic potential of acorns, woodland owners may have decided to conserve oak woods or even to transform other types of forests into oak woods. In addition, if such oak woods were used as pastures, such management led to subsequent changes in woodland composition and structure, connected with the prevention of forest succession. It is worth mentioning that according to Bobiec (2012), very high grazing pressure by large ungulate herbivores substantially limits oak regeneration. His observations of contemporary feeding stations located in Białowieża Forest indicate that high concentrations of bison effectively prevent oak recruitment. Moreover, López-Sánchez et al. (2014) observed reduction in density of oak seedlings and saplings, but not of adult trees in areas grazed by cattle. They concluded that the long-lasting presence of ungulates negatively affected oak regeneration, especially in pastures with a high stocking rate density.

\section{Palaeoecological context of the fungal spores record}

In central Europe, many human activities, e.g. deforestation, forest grazing and agriculture, significantly altered landscape structure and forest composition in the past (e.g. Behre, 1988). An important anthropogenic environmental change at or near settlement sites is eutrophication, resulting from the production of dung by high densities of domesticated herbivores (van Geel et al., 2003). Furthermore, man and domesticated animals are responsible for a range of new habitats, also, the mycoflora of settlement sites and the surrounding arable land, pastures and hay-meadows will have had different fungal assemblages relative to natural habitats.

Fungi that inhabit or are associated with the dung of animals are known as coprophilous fungi (Krug et al., 2004). These fungi are uniquely adapted to herbivore dung. Bell (1983) concluded that the spores of many coprophilous taxa are ingested by animals feeding on the plants, and then germinate after passing through the herbivores' digestive track.
The spores not only survive passage through the digestive system of animals, but also in most cases the mechanical and chemical digestion processes also benefit the germination of the spores on the dung substrates (Bell, 1983). Krug et al., (2004) underlined that germination, growth, and sporulation occur on freshly deposited dung. In the next phase, the spores are discharged forcefully into the air and readily adhere to nearby vegetation. Then, they will be consumed by herbivores, pass through their intestines, and again will be deposited with faeces (Bell, 2005). According to Krug et al. (2004), most of the coprophilous fungi are found on mammalian dung from domesticated farm animals, such as cattle, horses, and sheep; from wild mammals, both herbivorous and carnivorous; and from birds.

From the various studies of fossil and modern spores of coprophilous fungi (e.g. van Geel, 2001; Blackford and Innes, 2006; Graf and Chmura, 2006; van Geel and Aptroot, 2006) it became clear that the recorded spores in most cases were of strictly local occurrence. They were fossilized at, or near, the place where they had been produced, or the spores were deposited only a short distance from the place where sporulation took place. Consequently, spores of coprophilous fungi indicate nearby the former presence of dung produced by herbivores (van Geel et al., 2003). According to Lundqvist (1972), representatives of the Sordariaceae (Ascomycetes) are mostly coprophilous, particularly the genera Sporormiella, Podospora, Sordaria, and Cercophora, which are the most common ones among dung fungi (e.g. Krug et al. 2004; van Geel et al., 2007). Moreover, these fungi produce thick-walled spores that are well preserved in palynological preparations, and can be identified and counted alongside pollen, and this makes it feasible to use them in the category of secondary anthropogenic indicators (van Geel et al., 2003; López-Sáez and López-Merino, 2011).

Ejarque et al. (2011) analysed modern assemblages of pollen and NPP, and found useful relationships with vegetation and environmental patterns, as well as with grazing activities. The study included samples from herbivorous excrement in order to identify potential grazing indicators. These authors emphasized the significant role of coprophilous taxa, particularly of Sporormiella-type and Sordaria-type, as local indicators of herbivores. The spore cells of Sporormiella species, which include obligate coprophilous species growing on herbivore dung (Ahmed and Cain, 1972), are actually most often used to study the mid-to- late Holocene history of pastoral activities (e.g. Mighall et al., 2006; Currás et al., 2012).

Recently, López-Merino et al. (2014) indicated that Cercophora-type spores should be also regarded as good indicators of dung and grazing pressure. Fossil ascospores of the coprophilous Cercophora-type were first recognized by van Geel (1978). According to Ralska-Jasiewiczowa and van Geel (1992), the occurrence of Cercophora-type may be related to increased populations of large wild, and possible domesticated, herbivores. Cercophora species occur not only on dung, but also on decaying wood, culms, stems and leaves (Lundqvist, 1972). Moreover, Cugny et al. (2010) reported that Cercophora-type is more frequent in forested sites than elsewhere, and thus can be used as an indicator of grazing in a woodland. 
In our study the record of spores of coprophilous fungi (Sporormiella-type, Sordaria-type and Cercophora-type), in combination with pollen data, was used to identify animal-related agricultural practices in the vicinity of the studied site. In the first phase of human impact on the vegetation (LPAZ PG6-1, Fig. 2) frequently noted pollen of human impact indicators coincided with evidence of deforestation. The relatively high peaks of Poaceae, Apiaceae, Ranunculaceae, as well as numerous Filipendula and Centaurea nigra-type pollen (Fig. 2), document a large area of meadows rather than pastures. There were no Plantago lanceolata, Rumex acetosella-type, and almost no Rumex acetosa-type pollen, considered by Gaillard et al. (1992) as characteristic of grazed and mown grasslands, and indicators of animal husbandry. However, the presence of numerous charred particles, high frequencies of Artemisia, which is an indicator of ruderal communities and certain amounts of Chenopodiaceae point to significant activity within the settlement. In spite of the fact that human activity was intense at this phase, fungal spores were very scarce. Only Cercophora-type was present, but in small numbers and in only a few samples. It should be taken into consideration that wet local conditions may have limited both the local development of fungi and the frequentation of the site by animals (therefore, almost no dung may have been deposited). However, based on the pollen and fungal spore record from the first phase, it is possible that agriculture and animal husbandry did not play a key role in the close vicinity of the PG6 site. This is understandable if this first phase relates to the second phase of occupation of the hillfort at Poganowo, when an early medieval sacrificial place existed there, and mainly magical-religious rituals were performed. Agriculture was the most important human activity in the medieval period, and therefore we can say with a high degree of certainty that farmlands occurred at some distance from the investigated site. This interpretation is in agreement with the archaeological evidence of an early medieval human habitation in the Poganowo area.

The first phase was followed by a phase of decreased human activity (second phase, Fig. 2). However, pollen data from the PG6 profile indicate that some new land-use practices appeared in the second phase, but on a small local scale. The occurrence of Plantago lanceolata, Rumex acetosellatype, Rumex acetosa-type and Cichoriaceae pollen grains indicates that some open plant communities spread, probably as a result of grazing. Moreover, presence of spores of the coprophilous Cercophora-type, Sporormiella-type and Sordaria-type may confirm this type of activity in the close vicinity of the studied site. However, it remains an open question whether grazed plots were located in a forest or in areas outside the forest.

The third phase (LPAZ PG6-3) corresponds to the period of intensification of settlement processes that probably started from the late $13^{\text {th }}$ century AD onwards. Pollen data indicate changes in the woodland composition and show the frequent occurrence of human impact indicators. To some extent, the anthropogenic forest disturbances were probably related to the pasturing of livestock and firewood collecting. The increase of coprophilous fungi suggests that the livestock frequented the wetlands and fens located close to the sampling site, probably more often than before. It should be taken into account that over 4,500 fragments of animal bones were found during the archaeological investigations of the medieval sacrificial place at Poganowo (Wyczółkowski and Makowiecki, 2009) which might have functioned here even in the $13^{\text {th }}$ and $14^{\text {th }}$ centuries AD (M. Wyczółkowski, personal comm.). Almost 90\% were horse bones and about 10\% cattle bones. The authors estimated the minimum number of horse individuals at 60 . We suppose that cattle and horses were the dominant domesticated species in the study area. Moreover, in written sources (Beckherrn, 1885), a place called 'Stiermarkt' (bovine/cattle market) is mentioned and it is located a few kilometres from the sampling site. This toponym may confirm that grazing cattle played a significant role in this area in the past, but we cannot exclude an influence of game populations on the vegetation. However, typically, the spores of coprophilous fungi are occasionally present in the sediments and become very common only after the introduction of domesticated pasture animals (Graf and Chmura, 2006). According to Ejarque et al. (2011), dung-related fungi appear in much higher abundance in the excrement of domesticated animals than in the faeces of wild species, but the experimental research by Richardson (2001) showed that it is not possible to differentiate between fungal spectra from domestic (cattle, sheep, goat and horse) and wild (deer, elk) species.

It seems logical that the increase in Cercophora-type, Sordaria-type and Sporormiella-type that occurs in LPAZ PG6-3 (Fig. 2) implies a significant enhancement in grazing intensity and thus an increased population density of livestock near the investigated site. The higher frequencies of the spores of coprophilous fungi coincide with a noticeable increase of the spores of the parasitic fungus Kretzschmaria deusta, reaching a maximum frequency of ca. $12 \%$. The data from Poganowo may show that animals damaged the root system and the lower part of the trees by scraping bark away, hence allowing infection by this parasitic fungus. Moreover, the results of the PCA (Fig. 2) show that there is a correlation between dung-related fungi (Sordaria-type and Cercopho$r a$-type), the wood-rot fungus Kretzschmaria deusta and tree species such as Alnus, Carpinus betulus, Picea abies and Quercus. This may indicate that animals browsed mainly in woodland dominated by the above-mentioned tree species. Moreover, based on data from the topmost part of the PG6 pollen diagram (Fig. 2), where frequencies of Kretzschmaria deusta and Quercus change simultaneously, it could be concluded that this fungus might infected oaks more often than other trees. However, it should be taken into account that from the beginning of the LPAZ PG6-2 the local environment has changed, and the establishment of a local riparian and deciduous forest occurred, which permitted the presence of animals and, subsequently, spores of coprophilous fungi, as well as Kretzschmaria deusta.

Ascospores of Kretzschmaria deusta were previously identified as Ustulina deusta or as non-pollen microfossil 'Type HdV-44' by van Geel (1978), who also recognized that those spores were produced by a representative of the Xylariaceae. The fungus Kretzschmaria deusta (Hoffm.) P.M.D. Martin (Ustulina vulgaris Tul. and C. Tul; Ustulina deusta Hoffm.) is a tree pathogen that is also called brittle cinder, and it is found in temperate regions of the northern 
hemisphere (Rogers and Ju, 1998; van Geel et al., 2013). It causes soft-rot in wood, breaking down both cellulose and lignin, and it decays the trunk and roots of living trees. The fungus continues to decay wood after the host tree has died, making Kretzschmaria deusta a facultative parasite (Rogers and $\mathrm{Ju}, 1998)$. This fungus has a wide host range among broadleaved trees in Europe, including Acer, Aesculus, Alnus, Betula, Carpinus, Castanea, Fagus, Fraxinus, Populus, Quercus, Salix, Tilia and Ulmus. It has been rarely noted on Abies and Taxus (Wilkins, 1934). Although there is no evidence that Kretzschmaria occurs on Picea abies, potentially it can invade this tree (J. Rogers, personal comm.). Moreover, Schwarze (2007) showed experimentally the ability of Kretzschmaria deusta to cause decay in living spruce trees. Chlebicki (2008) reported that some xylariaceous fungi occur on Picea abies in Poland. Wilkins (1934) summarized many papers dealing with the pathogenicity of Kretzschmaria. It is an opportunistic parasite that takes advantage of already significantly damaged trees (Rogers and Ju, 1998). Open wounds on tree trunks are needed to account for major expansions of the fungus. Moreover, attacks by Kretzschmaria are usually associated with infections by some other fungi (Wilkins, 1934).

\section{CONCLUSIONS}

Integration of data from pollen, non-pollen palynomorph and microcharcoal particle analyses proved to be a useful tool for assessing human occupation of the Poganowo area. It is possible to distinguish three phases of vegetation dynamics connected with local human impact dated to the Middle Ages $\left(\mathrm{ca} 10^{\text {th }}-16^{\text {th }} \mathrm{c}\right.$.). The oldest, first phase, corresponds to very intensive human activity within the Poganowo settlement complex and relates to relatively large open areas created by regular human-caused burning. This region was, to a considerable extent, covered by meadows and ruderal communities, and only small plots were used as fields and pastures. The second phase was a period when human activity decreased and woodland regeneration took place. Finally, the third phase reflects response of a local vegetation to human activity dated to the $13^{\text {th }}-16^{\text {th }}$ centuries AD. Increasing ruderalisation and intensification of human impact were manifested by indicator species of trampled and grazed vegetation. The medieval management most probably promoted oaks and pastured oak woods. During the youngest part of this phase, a significant spread of Quercus was accompanied by an increase in spores of coprophilous fungi and the parasitic fungus Kretzschmaria deusta. We suppose that grazing animals caused damage to the roots and trunks of oak trees, thus triggering infections with Kretzschmaria deusta.

\section{Acknowledgements}

The study was part-financed by the Polish National Research Council (NCN), through project no. DEC-2011/01/B/HS3/04167. We would like to express our gratitude to Bas van Geel and Lionello Morandi for providing access to some of the specialized literature. We would like to thank Jack D. Rogers for valuable suggestions and comments on host-parasite association. We are grateful to Bas van Geel and an anonymous reviewer for their suggestions in improving this manuscript.

\section{REFERENCES}

Ahmed, S.E., Cain, R.F., 1972. Revision of the genera Sporormia and Sporormiella. Canadian Journal of Botany 50, 419-477.

Beckherrn, C., 1880. Rastenburg historisch-topographisch dargestellt, Verlag Schlemm, Kętrzyn.

Beckherrn, C., 1885. Verzeichnis der die Stadt Rastenburg betreffenden Urkunden, Altpreußische Monatsschrift 22, 505-605.

Beckherrn, C., 1889. Schaffer's Chronik von Rastenburg. Druck und Verlag von W. Kowalski, Rastenburg.

Behre, K.E., 1981. The interpretation of anthropogenic indicators in pollen diagrams. Pollen and Spores 23, 2, 225-245.

Behre, K.E., 1988. The role of man in European vegetation history. In: Huntley B., Webb T. (eds), Vegetation history, 633-672. Kluwer Academic Publishers, Dordrecht.

Bell, A., 1983. Dung fungi. An illustrated guide to coprophilous fungi in New Zealand Victoria University Press, Wellington.

Bell, A., 2005. An illustrated guide to coprophilous fungi Ascomycetes of Australia. CBS Biodiversity Series No. 3, Centraalbureau voor Schimmelcultures, Utrecht.

Berglund, B.E., Ralska-Jasiewiczowa, M., 1986. Pollen analysis and pollen diagrams. In: Berglund, B.E., Ralska-Jasiewiczowa M. (eds), Handbook of Holocene Palaeoecology and Palaeohydrology, 455-484.Wiley and Sons Ltd., Chichester-Toronto.

Beug, H.J., 2004. Leitfaden der Pollenbestimmung für Mitteleuropa und angrenzende Gebiete, Verlag Dr. Friedrich Pfeil, München.

Birks, H.J.B., 2003. Quantitative palaeoenvironmental reconstructions from Holocene biological data. In: Mackay A., Battarbee R.W., Birks H.J.B., Oldfield, F. (eds), Global Change in the Holocene, 342-357. Verlag Hodder Arnold, London.

Blackford, J.J., 2000, Charcoal fragments in surface samples following a fire and the implications for interpretation of subfossil charcoal data. Palaeogeography, Palaeoclimatology, Palaeoecology 164, 33-42.

Blackford, J.J., Innes, J.B., 2006. Linking current environments and processes to fungal spore assemblages: surface NPM data from woodland environments. Review of Palaeobotany and Palynology 141, 1, 179-187.

Bobiec, A., 2012. Białowieża Primeval Forest as a remnant of culturally modified ancient forest. European Journal of Forest Research 131, 5, 1269-1285.

Burchardt, L., Pawlik-Skowrońska, B., 2005. Zakwity sinic - konkurencja międzygatunkowa i środowiskowe zagrożenie. Wiadomości Botaniczne 49,1-2, 39-49.

Chlebicki, A., 2008. Some overlooked and rare xylariaceous fungi from Poland. Polish Botanical Journal 53, 1, 69-70.

Connor, S.E., Araújo, J., van der Knaap, W.O., van Leeuwen, J.F.N., 2012. A long-term perspective on biomass burning in the Serra da Estrela, Portugal. Quaternary Science Reviews 55, $114-124$.

Cugny, C., Mazier, F., Galop, D., 2010. Modern and fossil non-pollen palynomorphs from the Basque mountains (western Pyrenees, France): the use of coprophilous fungi to reconstruct pastoral activity. Vegetation History and Archaeobotany 19, 391-408.

Currás, A., Zamora, L., Reed, J.M., García-Soto, E., Ferrero, S., Armangol, X., Mezquita-Joanes, F., Marqués, M.A., Riera, S., Juliŕ, R., 2012. Climate change and human impact in central Spain during Roman times: high-resolution multi-proxy analysis of a tufa lake record (Somolinos, 1,280 m asl). Catena 89, $31-53$.

Ejarque, A., Miras, Y., Riera, S., 2011. Pollen and non-pollen palynomorph indicators of vegetation and highland grazing activities obtained from modern surface and dung datasets in the eastern Pyrenees. Review of Palaeobotany and Palynology 
$167,123-139$

Faliński, J.B., 1986. Vegetation dynamics in temperate lowland primeval forest. In Faliński, J.B., (ed.), Geobotany, 39-111. Dr. W. Junk Publishers, Dordrecht.

Flannery, T., 2003. Monkeys and trees. In: Craven, P. (ed.), The Best Australian Essays 2003, 528-549. Black Inc. Publishing, Melbourne.

Gaillard, M.J., Berglund, B.E., 1988. Land-use history during the last 2700 years in the area of Bjäresjö, Southern Sweden. In Birks, H., Birks, H.J.B., Kaland, P.E., Moe D., (eds), The cultural landscape: past, present and future, 409-428. Cambridge University Press, Cambridge.

Gaillard, M.J., Birks, H.J.B., Emanuelsson, U., Berglund, B.E., 1992. Modern pollen/land-use relationships as an aid in the reconstruction of past land-uses and cultural landscapes: an example from south Sweden. Vegetation History and Archaeobotany $1,3-17$.

Gerullis, G., 1922. Die altpreussischen Ortsnamen gesammelt und sprachlich behandelt. Vereinigung wissenschaftlicher Verlag Walter de Gruyter \& Co., Berlin-Leipzig.

Graf, M.T., Chmura, G., 2006. Development of modern analogues for natural, mowed and grazed grasslands using pollen assemblages and coprophilous fungi. Review of Palaeobotany and Palynology 141, 139-149.

Goldbeck, J.F., 1785. Vollständige Topographie vom Ost-Preußischen Cammer-Departemet. In Goldbeck, J.F. (ed.), Vollständige Topographie des Königreichs Preußen, Erster Teil, Topographie von Ostpreußen, Königsberg und Leipzig [Sonderschriften des Vereins für Familienforschung in Ost- und Westpreussen e.V., 7]. Hamburg.

Gross, H., 1935. Der Döhlauer Wald in Ostpreußen. Eine bestandesgeschichtliche Untersuchung. Beihefte zum Botanischen Centralblatt 53 B. Pascher, 405-431.

Hartig, K., Beck, E., 2003. The bracken fern (Pteridium arachnoideum (Kaulf.) Maxon) dilemma in the Andes of Southern Ecuador. Ecotropica 9, 3-13.

Hjelle, K.L., 1999. Modern pollen assemblages from mown and grazed vegetation types in western Norway. Review of Palaeobotany and Palynology 107, 55-81.

Hoffmann, M.J., 1999. ródła do kultury i osadnictwa południowowschodniej strefy nadbałtyckiej w I tysiącleciu p.n.e. Wydawnictwo OBN, Olsztyn.

Huntley, B., Birks, H.J.B., 1983. An atlas of past and present pollen maps for Europe 0-13,000 years ago. Cambridge University Press, Cambridge.

Jankovská, V., Komárek, J., 2000. Indicative value of Pediastrum and other coccal green algae in palaeoecology. Folia Geobotanica $35,59-82$.

Krug, J.C., Benny, G.L., Keller, H.W., 2004. Coprophilous fungi. In Mueller, G.M., Bills, G.F., Foster, M.S. (eds), Biodiversity of fungi: inventory and monitoring methods, 468-499. Elsevier Academic Press, Burlington, Massachusetts.

Kwiatkowska, A.J., Spalik, K., Michalak, E., Palińska, A., Panufnik, D., 1997. Influence of the size and density of Carpinus betulus on the spatial distribution and rate of deletion of forest-floor species in thermophilous oak forest. Plant Ecology $129,1-10$

Latałowa, M., 2007. Gospodarka człowieka w diagramach pyłkowych. In Makohonienko, M., Makowiecki, D., Kurnatowska, Z., (eds) Studia interdyscyplinarne nad środowiskiem i kulturą w Polsce, 171-187. Ser. Wyd. Stowarzyszenie Archeologii Środowiskowej Środowisko-Człowiek-Cywilizacja. tom. 1 Poznań.

Latałowa, M., Pędziszewska, A., Maciejewska, E., Święta-Musznicka, J., 2013. Tilia forest dynamics, Kretzschmaria deusta attack, and mire hydrology as palaeoecological proxies for
mid-Holocene climate reconstruction in the Kashubian Lake District (N Poland). The Holocene 23, 5, 667-677.

Lindbladh, M., Niklasson, M., Nilsson, S.G., 2003. Long-time record of fire and open canopy in a high biodiversity forest in southeast Sweden. Biological Conservation 114, 231-243.

López-Merino, L., Cortizas, A.M., Reher, G.S., López-Sáez, J.A., Mighall, T.M., Bindler, R., 2014. Reconstructing the impact of human activities in a NW Iberian Roman mining landscape for the last 2500 years. Journal of Archaeological Science 50, 208-218.

López-Sáez, J.A., López-Merino, L. 2011. Coprophilous fungi as a source of information of anthropic activities during the Prehistory in the Amblés Valley (Ávila, Spain): the archaeopalynological record. Revista Espańola de Micropaleontología 39, $1-2,103-116$.

López-Sánchez, A., Schroeder, J., Roig, S., Sobral, M., Dirzo, R. 2014. Effects of Cattle Management on Oak Regeneration in Northern Californian Mediterranean Oak Woodlands. PloS One 9, 8, 105-472.

Lundqvist, N., 1972. Nordic Sordariaceae s. lat. Symbolae Botanicae Upsalienses 20, 1-374.

Maron, J.L., Crone, E., 2006. Herbivory: effects on plant abundance, distribution and population growth. Proceedings of the Royal Society B: Biological Sciences 273, 1601, 2575-2584.

Mazier, F., Galop, D., Brun, C., Buttler, A., 2006. Modern pollen assemblages from grazedvegetation in the western Pyrenees, France: a numerical tool for more precise reconstruction of past cultural landscapes. The Holocene 16, 1, 91-103.

Mighall, T.M., Martínez-Cortizas, A., Biester, H., Turner, S.E., 2006. Proxy climate and vegetation changes during the last five millennia in NW Iberia: pollen and non-pollen palynomorph data from two ombrotrophic peat bogs in the North Western Iberian Peninsula. Review of Palaeobotany and Palynology 141, 203-223.

Nalepka, D., Walanus, A., 2003. Data processing in pollen analysis. Acta Palaeobotanica 43, 1, 125-134.

Nowakiewicz, T., 2006. Galindia in the Viking Age-New Shape of the Culture. In Bertašius, M., (ed.), Transformatio Mundi. The Transition from the Late Migration Period to the Early Viking Age in the East Baltic, 161-172. Kaunas University, Kaunas.

Nowakiewicz, T., 2010. Some remarks on settlement systems of Early Medieval Prussians. The case of northern Galindia. In Lund Hansen, U., Bitner-Wróblewska, A., (eds), Worlds apart? Contacts across the Baltic Sea in the Iron Age. Network Denmark-Poland, 2005-2008, 487-504. Nordiske Fortidsminder C 7, Křbenhavn-Warszawa.

Nowakiewicz, T., Wróblewski, W. 2010. „Pruzzische“ und „slawische“ Keramik im frühmittelalterlichen Galinden. In Lund Hansen, U., Bitner-Wróblewska, A., (eds), Worlds apart? Contacts across the Baltic Sea in the Iron Age. Network Denmark-Poland, 2005-2008, 505-524. Nordiske Fortidsminder C 7, Křbenhavn-Warszawa.

Pokorná, A., Houfková, P., Novák, J., Bešta, T., Kovačiková, L., Nováková, K., Zavřel, J., Starec, P., 2014. The oldest Czech fishpond discovered? An interdisciplinary approach to reconstruction of local vegetation in mediaeval Prague suburbs. Hydrobiologia 730, 1, 191-213.

Rackham, O., 1988. Trees and woodland in a crowded landscapeThe cultural landscape of the British Isles. In Birks, H.H., Birks, H.J., Kaland, P.E. et al. (eds), The Cultural LandscapePast, Present and Future, 53-77. Cambridge University Press, Cambridge.

Raddatz, K., 1992/93. Der Wolka-See, ein Opferplatz der Römischen Kaiserzeit in Ostpreußen, Offa 49/50, 127-187.

Ralska-Jasiewiczowa, M., van Geel, B., 1992. Early Human disturbance of natural environment recorded in annually laminated 
sediments of Lake Gościąż, central Poland. Vegetation History and Archaeobotany 1, 33-42.

Richardson, M.J., 2001. Diversity and occurrence of coprophilous fungi. Mycological Research 105, 4, 387-402.

Rogers, J.D., Ju, Y.M., 1998. The genus Kretzschmaria. Mycotaxon 68, 345-393.

Saage, J.M., Woelky, C.P., 1860. Codex diplomaticus Warmiensis oder Regesten und Urkunden zur Geschichte Ermlands. Bd. 1, Urkunden der Jahre 1231-1340, Verlag von Franz Kirchheim, Mainz.

Schwarze, F.W., 2007. Wood decay under the microscope. Fungal Biology Reviews 21, 4, 133-170.

Stockmarr, J., 1971. Tablets with spores used in absolute pollen analysis. Pollen Spores 13, 615-621.

Sugita, S., 2007. Theory of quantitative reconstruction of vegetation. I. Pollen from large sites REVEALS regional vegetation composition. The Holocene 17, 229-241.

Szabó, P., 2013. Rethinking pannage: Historical interactions between oak and swine. In Rotherham, I.D., (ed.), Trees, Forested Landscapes and Grazing Animals: A European Perspective on Woodlands and Grazed Treescapes, 51-61. Routledge, Abingdon.

Szal, M., Kupryjanowicz, M., Wyczółkowski, M., 2013. Lokalny charakter zmian roślinności w sąsiedztwie kompleksu osadniczego w Poganowie (Pojezierze Mragowskie). In Ciecierska, H., Hołdyński, Cz. (eds), Dziedzictwo przyrodnicze Warmii, Mazur i Powiśla. Interdyscyplinarne i aplikacyjne znaczenie nauk botanicznych, 339-349. Wydawnictwo Mantis, Olsztyn.

Szal, M., Kupryjanowicz, M., Wyczółkowski, M., Tylmann, W., 2014. The Iron Age in the Mragowo Lake District, Masuria, NE Poland: the Salęt settlement microregion as an example of long-lasting human impact on vegetation. Vegetation History and Archaeobotany 23, 417-437.

Szymański, P., 2005. Mikroregion osadniczy z okresu wpływów rzymskich w rejonie jeziora Salęt na Pojezierzu Mazurskim. Światowit Supplement Series P: Prehistory and Middle Ages 10. Wydawnictwo IA UW, Warszawa.

Tinner, W., Conedera, M., Gobet, E., Hubschmid, P., Wehrli, M. and Ammann, B., 2000. A palaeoecological attempt to classify fire sensitivity of trees in the southern Alps. The Holocene 10, $565-574$.

Tinner, W., Hu, F. S., 2003. Size parameters, size-class distribution and area-number relationship of microscopic charcoal: relevance for fire reconstruction. The Holocene 13, 4, 499-505.

van Geel, B., 1978. A palaeoecological study of Holocene peat bog sections in Germany and The Netherlands. Review of Palaeobotany and Palynology 25, 1-120.

van Geel, B., 2001. Non-pollen palynomorphs. In Smol, J.P., Birks, H.J.B., Last, W.M., (eds), Tracking Environmental Change Using Lake Sediments, Volume 3, 99-119. Kluwer, Dordrecht.

van Geel, B., Grenfell, H.R., 1996. Spores of Zygnemataceae (Chapter 7A). In Jansonius, J., McGregor, D.C., (eds), Palynology: principles and applications, 173-179. American Association of Stratigraphic Palynologists Foundation, Dallas. van Geel, B., Buurman, J., Brinkkemper, O., Schelvis, J., Aptroot, A., van Reenen, G., Hakbijl, T., 2003. Environmental reconstruction of a Roman Period settlement site in Uitgeest (The Netherlands), with special reference to coprophilous fungi. Journal of Archaeological Science 30, 873-883.

van Geel, B., Aptroot, A., 2006. Fossil ascomycetes in Quaternary deposits. Nova Hedwigia 82, 313-329.

van Geel, B., Zazula, G.D., Schweger, C.E., 2007. Spores of coprophilous fungi from under the Dawson tephra $(25,30014$ C years BP), Yukon Territory, northwestern Canada. Palaeogeography, Palaeoclimatology, Palaeoecology 252, 3, 481485 .

van Geel, B., Engels, S., Martin-Puertas, C., Brauer, A., 2013. Ascospores of the parasitic fungus Kretzschmaria deusta as rainstorm indicators during a late Holocene beech-forest phase around lake Meerfelder Maar, Germany. Journal of Paleolimnology 50, 1, 33-40.

van der Linden, M., Kooistra, L.I., Engels, S., 2012. Non-pollen palynomorphs as relevant indicators in palaeoecology and archaeobotany. Review of Palaeobotany and Palynology 186, 1 .

Visitation, 1571. Visitation und Inventirung der Kirchen Rastenburgk [...] Anno 1571 - Im Octobri den 15; manuscript belonging to the Wojciech Kętrzyński Museum, Ketrzyn.

Voß, G., 1886. Ein Gräberfeld der ersten Jahrhunderte n. Chr. Geburt in Gr. Thurwangen, Prussia Berichte 11, 55-59.

Vuorela, I., 1973. Relative pollen rain around cultivated fields. Acta Botanica Fennica 102, 1-27.

Whitlock, C., Larsen, C., 2001. Charcoal as fire proxy. In Smol, J.P., Last, W.M., (eds), Terrestrial, algal and siliceous indicators. Tracking environmental change using lake sediments, vol 3, 75-97. Kluwer Academic Publishers, Dordrecht.

Wilkins, W.H., 1934. Studies in the genus Ustulina with special reference to parasitism. I. Introduction, survey of previous literature and host index. Transactions of the British Mycological Society $18,320-346$.

Wyczółkowski, M., 2011. Archeologia leśna. Nowe metody, nowe perspektywy. Muzeum im. W. Kętrzyńskiego, Kętrzyn.

Wyczółkowski, M., Makowiecki, D., 2009. Horse sacrifices in Prussia in the early Middle Ages. Ritual area in Poganowo Site IV, Olsztyn Province (Poland), Archaeologia Baltica 11, 295304.

Wyczółkowski, M., Szal, M., Kupryjanowicz, M., Smolska, E., 2013. Kompleks osadniczy w Poganowie, pow. kętrzyński, stanowisko IV: wstępne wyniki badań interdyscyplinarnych. In Kobyliński, Z., (ed.), Grodziska Warmii i Mazur 1. Stan wiedzy i perspektywy badawcze. Archaeologica Hereditas 2, 65-82. Uniwersytet Kardynała Stefana Wyszyńskiego w Warszawie, Wydawnictwo Fundacji Archeologicznej, WarszawaZielona Góra.

XLSTAT 2014 http://www.xlstat.com

Zarzycki, K., 2002. Ecological indicator values of vascular plants of Poland (Ekologiczne liczby wskaźnikowe roślin naczyniowych). Instytut Botaniki im. W. Szafera PAN, Kraków. 